Pak. j. sci. ind. res. Ser. B: biol. sci. 2016 59(3) 139-145

\title{
Biochemical Characterisation and Dietary Fibre Analysis of Sugar Beet Supplemented Cookies
}

\author{
Imran Pasha, Muhammad Farhan Jahangir Chughtai*, Sabeen Akhter, \\ Aysha Sameen and Muhammad Sajid Manzoor \\ National Institute of Food Science and Technology, University of Agriculture, Faisalabad, Pakistan
}

(received February 1, 2016; revised May 12, 2016; accepted May 19, 2016)

\begin{abstract}
This study was planned to utilize sugar beet powder as a rich source of dietary fibre in cookies. Purposely, five treatments namely $\mathrm{T}_{1}, \mathrm{~T}_{2}, \mathrm{~T}_{3}, \mathrm{~T}_{4}$ and $\mathrm{T}_{5}$ with $4 \%, 8 \%, 12 \%, 16 \%$ and $20 \%$ sugar beet powder addition in wheat flour were chosen to estimate fibre, antioxidant profiling and engineering properties of cookies. Results showed an increased content of all above mentioned parameters. With the increment in sugar beet powder addition in treatments, dietary fibre analysis have shown that total dietary fibre (TDF), insoluble dietary fibre (IDF) and soluble dietary fibre (SDF) have depicted increasing trend with maximum for $\mathrm{T}_{5}$ for all dietary fibre types. Significant results were obtained for in vitro antioxidant studies including total phenolic content (TPC) and DPPH that showed increasing trend with $\mathrm{T}_{1} 0.6 \mathrm{mg}$ $\mathrm{GAE} / \mathrm{g}$ and maximum values for $\mathrm{T}_{5}$ with $2.0 \mathrm{mg} \mathrm{GAE} / \mathrm{g}$ for TPC and for DPPH with $\mathrm{T}_{5}$ being maximum value of $1.7 \%$ and minimum for $\mathrm{T}_{1}$ with $1.3 \%$. $\mathrm{T}_{5}$ treatment with $20 \%$ sugar beet gave best physicochemical results but disturbed sensory properties while $\mathrm{T}_{3}$ with $12 \%$ sugar beet powder showed good physicochemical and sensory characteristics. Therefore, $\mathrm{T}_{3}$ with $12 \%$ level is considered as the best source of dietary fibre in bakery products and can be considered as the prospective choice to address metabolic syndromes.
\end{abstract}

Keywords: sugar beet, dietary fibre, biochemical characterisation, cookies, sensory analysis

\section{Introduction}

Changing dietary patterns have led to preparation of certain health endorsing foods. Amongst, dietary fibre holds paramount importance in addressing various lifestyle related disorders.

In this regard people put their health at stake and adopt such dietary patterns that are health deteriorating leading to various ailments. In this regard they use junk foods that are deficient in dietary fibres. Therefore, to fulfill this need, sugar beet can be used as a good dietary fibre provider.

Sugar beet (Beta vulgaris) a good source of energy, nutrition and dietary fibre belongs to the family Chenopodiaceae (Ahmad et al., 2012). It has many varieties of different shapes and colours. Sugar beet has a characteristic barn, silage like, musty or strong earthy odour because of two main compounds namely: geosmin (tarns-1,10-dimemyltrans-(9)-decalol) and 2-methoxy-3-sec-butylpyrazine (Lu et al., 2003). It is a potential source of phenolic and potent antioxidant compound with significant amount of various vital phenolic acids (Vulic et al., 2012) with chlorogenic, gallic, gentisic, ferulic and coumeric acids (Belal, 2007; Sakac et al., 2004; Brand-Williams et al., *Author for correspondence; E-mail: m.farhan.chughtai@hotmail.com
1995). Ferulic acid, a potent antioxidant is much higher in sugar beet as compared to wheat flour and wheat bran.

It is a good source of minerals and vitamins especially; vitamin $\mathrm{A}, \mathrm{C}$, folate, potassium, sodium, magnesium, calcium, iron, copper and zinc (Skrbic et al., 2010). It contains betaine along with folic acid, vitamin $\mathrm{B}_{12}$ and vitamin $\mathrm{B}_{6}$ which helps to reduce higher levels of homocysteine (Schnyder et al., 2002). Sugar beet is also high in bio-flavonoids and has half sweetness than sucrose therefore more suitable for hyperglycemic patients (Vulic et al., 2012).

Almost $70 \%$ total dietary fibre of sugar beet composed of $1 / 3^{\text {rd }}$ soluble fibre and $2 / 3^{\text {rd }}$ insoluble fibre (Filipovic et al., 2007). Being a good source of dietary fibre it reduces the risk of cancers, obesity, diabetes, gallstone formation and heart diseases; prevents and treats constipation and cures diverticulitis (Ahmad et al., 2012). Besides providing health benefits, it also performs certain functional properties in food products i.e., it can act as antioxidant, anticaking, binding, bulking, dispersing, thickening, stabilizing and texturizing agent in various food products like patties, sauces, sausages, snacks, fruit fillings, yogurt, beverages and bakery (Ralet et al., 2009; Thibault et al., 2001). 
Due to its various health benefits there is an increasing demand of dietary fibre in food products. Recommendations for daily dietary fibre (DF) intake vary from country to country with a range 18-38 g/day, of which $38 \mathrm{~g} /$ day is for men and $26 \mathrm{~g} /$ day is recommended for women (Rodriguez et al., 2006). Based on 2010 con-sumption data, sugar beet fibre consumption by humans was about $97522.35 \mathrm{~kg}$ of which about $29545 \mathrm{~kg}$ approx. was consumed in the form of baked goods such as bread, cakes and cookies while, $59090 \mathrm{~kg}$ was consumed in health products in the form of fibre tablets (Galisteo et al., 2008).

Fibre from sugar beet can be better utilised in bakery products by making its composite with wheat flour. In bakery products cookies have been recommended as a better utilisation of composite flour than bread because of their ready to eat form, excellent eating quality, and greater consumption and extended shelf life (Okpala and Chinyelu, 2011; Piga et al., 2005). Since cookies are usually prepared from wheat flour with about $72 \%$ extraction rate i.e., without bran and germ which causes low dietary fibre content $(<2.5 \%)$, low protein content (7 to 10\% ) lacking certain essential amino acids (lysine, tryptophan and threonine), low vitamin and mineral content of cookies (McWatters et al., 2003).

The main objective to produce composite flour is to acquire a product which is better than its individual components, improved performances and economy. Composite flour knowledge has been used as a tool for extending short supplies of wheat and corn in the formulation of baked products (Okpala and Chinyelu, 2011; Piga et al., 2005).

In the present study, sugar beet powder is being used as a fibre source in cookies formulation. For this purpose its powder was replaced by wheat flour at various substitution levels to produce composite flour. The research of Thibault et al. (2001) indicated that sugar beet fibre with its odourless and colourless properties has potential to be used as a dietary fibre source in cookies but exceeding its level from 16\% disturbed sensory properties of cookies. Various studies indicated that more than $20 \%$ addition of sugar beet alters the rheological properties of bakery products. This composite flour is being used in cookies preparation with the objective of better nutrition and a fibre enriched end product with excellent overall acceptability.

\section{Materials and Methods}

Procurement of raw material. Commercially available varieties of sugar beet were purchased from Ayub Agricultural Research Institute (AARI), Faisalabad. Chemicals were purchased from Sigma Aldrich and local market.

Preparation of sugar beet powder. Sugar beets were washed to remove adhering contaminants followed by peeling and cossette preparation. The cossettes were dried by dehydrator as described by Filipovic et al. (2007) at $30-35{ }^{\circ} \mathrm{C}$ for $24 \mathrm{~h}$ and coarsely powdered by grinder, sieved and then stored in polythene bags.

Chemical analyses. The commercial white wheat flour and sugar beet powder were tested for their proximate analyses according to AACC (2000) i.e., moisture content with method No. 44-15A, crude protein with method No. 46-10, crude fat 30-10, crude fibre method No. 32-10 and ash content with method No. 08-01.

Dietary fibre analyses. The sugar beet powder and the cookies were analysed for total dietary fibre, soluble dietary fibre and insoluble dietary fibre according to AACC (2000) as mentioned and described below:

Total dietary fibre (TDF). The sugar beet powder and the cookies were analysed for total dietary fibre according to AACC (2000) method No. 32-05. The sample was dispersed in a buffer solution and incubated with heat-stable $\alpha$-amylase at $95-100{ }^{\circ} \mathrm{C}$ for $40 \mathrm{~min}$. After cooling the samples up to $60^{\circ} \mathrm{C}$, these contents were incubated at $60{ }^{\circ} \mathrm{C}$ for $30 \mathrm{~min}$ with addition of $100 \mu \mathrm{L}$ protease solutions. Finally contents were incubated with amyloglucosidase enzyme at $60{ }^{\circ} \mathrm{C}$ for $30 \mathrm{~min}$. Total dietary fibre was precipitated with the addition of ethyl alcohol in 1:4 ratio. The contents were filtered and washed with ethyl alcohol and acetone. A blank sample was run throughout entire method with samples to determine any contribution from reagents to residue. The TDF was calculated by the following formula:

$$
(\%) \mathrm{TDF}=\frac{\text { Residue } \mathrm{wt}-\text { protein }- \text { ash }- \text { blank }}{\text { Sample weight }} \times 100
$$

Soluble dietary fibre (SDF). The samples were investigated for soluble dietary fibre by following the method as given in AACC (2000) method No. 32-07, by utilising Megazyme assay kit (Megazyme, Ireland). The samples were dispersed in buffer solution and incubated with heat stable $\alpha$-amylase at $95-100{ }^{\circ} \mathrm{C}$ for $35 \mathrm{~min}$. After 
cooling, samples were again incubated with addition of $100 \mu \mathrm{L}$ protease solution at a temperature of $60^{\circ} \mathrm{C}$ for $30 \mathrm{~min}$. Finally, the residue was incubated with amyloglucosidase at a temperature of $60{ }^{\circ} \mathrm{C}$ for $30 \mathrm{~min}$. After filtration, residue was washed and rinsed with 10 $\mathrm{mL}$ distilled water. The filtrate was weighed and soluble dietary fibre (SDF) was precipitated with four volumes of ethyl-alcohol. The contents were filtered, dried and analysed for protein and ash content. A blank sample was also run through entire protocol along with samples to observe any contribution from reagents to residues. The soluble dietary fibre was calculated with the following expression:

$$
(\%) \mathrm{SDF}=\frac{\text { Residue wt }- \text { protein }- \text { ash }- \text { blank }}{\text { Sample weight }} \times 100
$$

Insoluble dietary fibre (IDF). Insoluble dietary fibre (IDF) in different samples was estimated by using the method as mentioned in AACC (2000) method No. 3220 . The samples were dispersed in a buffer solution and incubated with heat stable $\alpha$-amylase at $95-100{ }^{\circ} \mathrm{C}$ for $35 \mathrm{~min}$. After cooling, contents were again incubated with addition of $100 \mu \mathrm{L}$ protease enzyme at $60{ }^{\circ} \mathrm{C}$ for $30 \mathrm{~min}$ and then the contents were incubated with amyloglucosidase enzyme at $60{ }^{\circ} \mathrm{C}$ for $30 \mathrm{~min}$. After filtration, remaining material was washed and rinsed with $10 \mathrm{~mL}$ water. The resultant residue was weighed and insoluble dietary fibre was precipitated with four volume of ethyl-alcohol. The contents were filtered, dried and corrected for protein and ash content. A blank was also run through same method to measure any contribution from reagents to residue. The IDF was calculated by the following expression:

$$
(\%) \mathrm{IDF}=\frac{\text { Residue wt }- \text { protein }- \text { ash }- \text { blank }}{\text { Sample weight }} \times 100
$$

Antioxidant potential of sugar beet. Antioxidant potential of sugar beet was determined by following their respective methods. The free phenolic acids in sugar beet powder were extracted using the method described by Sakac et al. (2010). Sugar beet powder $10 \mathrm{~g}$ was mixed with $100 \mathrm{~mL}$ of $96 \%$ ethanol. This mixture was shaken at room temperature for $1 \mathrm{~h}$ using orbital shaker. Extract was filtered through Whatmann \#1 filter paper and then dried. Dried extract was again dissolved in $96 \%$ ethanol up to $10 \mathrm{~mL}$ final volume using distilled water. Extracted contents were used for the determination of total phenolic content and radical scavenging activity using DPPH method.
Determination of total phenolic content (TPC). The total phenolic compounds in sugar beet powder and cookies were estimated by some modifications in the Folin-Ciocalteu method (FCM) described by Sakac et al. (2010) and Ainsworth and Gillespie (2007). From a known concentration of the sample solution, $125 \mu \mathrm{L}$ sample was taken in test tube. Then $500 \mu \mathrm{L}$ distilled water was added in it. After that $125 \mu \mathrm{L}$ of FolinCiocalteu reagent was added in it and given a standing time of almost $6 \mathrm{~min}$. Then $1.25 \mathrm{~mL}$ of $7 \%$ sodium carbonate was added in it. Final volume was made $3 \mathrm{~mL}$ by adding $1 \mathrm{~mL}$ of distilled water and given $90 \mathrm{~min}$ for completion of reaction.

Absorbance of the samples was measured in triplicate at $750 \mathrm{~nm}$ using a UV-Vis spectrophotometer (IRMECO Germany). Gallic acid was run as a standard along with the samples and its absorbance was also taken at $750 \mathrm{~nm}$. TPC was calculated by the following formula:

$$
\mathrm{C}=\mathrm{c} \times \mathrm{V} / \mathrm{m}
$$

where:

$$
\begin{aligned}
& \mathrm{C}=\text { total contents of phenolic compounds }(\mathrm{mg} / \mathrm{GAE} / \mathrm{g}) \\
& \mathrm{c}=\text { concentration of gallic acid }(\mathrm{mg} / \mathrm{mL}) \\
& \mathrm{V}=\text { the volume of the extract } \\
& \mathrm{m}=\text { weight of extract }(\mathrm{g})
\end{aligned}
$$

Radical scavenging activity by using DPPH method. The antioxidant activity of ethanolic extract of sugar beet powder and cookies was determined based on the radical scavenging ability in reacting with a stable DPPH free radical (Mohdaly et al., 2010; Sakac et al., 2010). In this method, $4 \mathrm{mg}$ of DPPH was dissolved in $100 \mathrm{~mL}$ methanol and $2 \mathrm{~mL}$ of this solution was added to $50 \mu \mathrm{L}$ ethanolic extract. The mixture was shaken vigorously and allowed to stand at room temperature in the dark for $60 \mathrm{~min}$. Then the absorbance was measured at $517 \mathrm{~nm}$ against blank. The radical scavenging percentage was calculated using the following equation:

$$
\begin{aligned}
& \text { Reduction of absorbance }(\%)= \\
& {[(\mathrm{AB}-\mathrm{AA}) / \mathrm{AB}] \times 100}
\end{aligned}
$$

where:

$$
\begin{aligned}
\mathrm{AB}= & \text { absorbance of blank sample }(\mathrm{t}=0 \mathrm{~min}) \\
\mathrm{AA}= & \text { absorbance of tested extract solution } \\
& (\mathrm{t}=15 \mathrm{~min})
\end{aligned}
$$

Cookies preparation. Cookies were prepared according to the treatment plan shown in Table 1 by following the method no. 10-54 as mentioned in AACC (2000) from 
wheat flour-sugar beet powder composite flour using different percentages as described below:

$\mathrm{T}_{0}=100 \%$ wheat flour; $\mathrm{T}_{1}=96 \%$ wheat flour + $4 \%$ sugar beet powder; $\mathrm{T}_{2}=92 \%$ wheat flour + $8 \%$ sugar beet powder; $\mathrm{T}_{3}=88 \%$ wheat flour + $12 \%$ sugar beet powder; $\mathrm{T}_{4}=84 \%$ wheat flour + $16 \%$ sugar beet powder; $\mathrm{T}_{5}=80 \%$ wheat flour + $20 \%$ sugar beet powder

Sensory evaluation of cookies. Cookies were analysed according to the procedure described by Lawless and Heymann (2010).

Statistical analysis. The collected data was statistically analysed according to the procedure described by Montogomery et al. (2008). The design applied on the data obtained is completely randomized design (CRD).

Table 1. Treatments used for the product development

\begin{tabular}{lll}
\hline \hline Treatments & $\begin{array}{l}\text { Wheat flour } \\
(\%)\end{array}$ & $\begin{array}{l}\text { Sugar beet powder } \\
(\%)\end{array}$ \\
\hline $\mathrm{T}_{0}$ & 100 & - \\
$\mathrm{T}_{1}$ & 96 & 04 \\
$\mathrm{~T}_{2}$ & 92 & 08 \\
$\mathrm{~T}_{3}$ & 88 & 12 \\
$\mathrm{~T}_{4}$ & 84 & 16 \\
$\mathrm{~T}_{5}$ & 80 & 20 \\
\hline \hline
\end{tabular}

\section{Results and Discussion}

The present project was designed to investigate various physicochemical attributes of sugar beet powder. The main intention of present project was to optimize sugar beet powder quantity as a potential fibre source in cookies production and evaluation of sugar beet fibre cookies for sensory, physical and quality parameters.

Chemical composition of wheat flour. The proximate composition of wheat flour and of sugar beet powder is shown in Table 2. The results pertaining proximate composition of wheat flour revealed that the white flour contained $11 \%$ moisture, $1.4 \%$ total ash, $10 \%$ crude protein, $2.5 \%$ crude fat, $0.5 \%$ crude fibre and $73.2 \%$ NFE content. The results obtained in the present study for the analyses of wheat flour are in close agreement with Ahmad et al. (2009), who analysed different wheat varieties and observed 12.5 to $14.6 \%$ moisture, 8.23 to $12.71 \%$ protein, 1.17 to $1.59 \%$ fat, 0.42 to $0.76 \%$ crude fibre and 0.42 to $0.66 \%$ ash content. Kendler (2006) also analysed wheat varieties for their proximate composition and found that values ranged from 12.49 to $13.27 \%$ for moisture, 10.84 to $11.98 \%$ for protein, 0.68 to $0.96 \%$ for crude fibre and 0.40 to $0.58 \%$ for ash contents.

The proximate analysis of sugar beet powder revealed that it contained 5.1\% moisture, $5.0 \%$ ash, $6.1 \%$ crude protein, $0.8 \%$ crude fat, $9.0 \%$ crude fibre and $74 \%$ NFE content. The results obtained in the present study for the proximate analysis of sugar beet powder are in accordance to the findings of McWatters et al. (2003) who observed $6.8 \%$ crude protein, $0.6 \%$ crude fat and $5.5 \%$ ash content, with previous study of Westenhoefer (2001) who analysed 4.6\% moisture content in sugar beet and also in close agreement with previous study of Belal (2007) who found 12.73 and $18.7 \%$ crude fibre in different sugar beet varieties, respectively.

Total dietary fibre, soluble dietary fibre and insoluble dietary fibre content in sugar beet powder was $31 \%$, $10 \%$ and $21 \%$, respectively as shown in Table 2 . These findings were in consistence with the outcomes of other researchers (Sakac et al., 2010; Filipovic et al., 2007). Total phenolic content of sugar beet powder was expressed in terms of gallic acid equivalent (GAE) per gram of sugar beet powder from which the extract was obtained and was found to be $1.18 \mathrm{mg} \mathrm{GAE} / \mathrm{g}$. The values of total phenolic content in this study are in accordance with the values as observed by Mohdaly et al. (2010). DPPH radical scavenging activity of sugar beet powder was expressed in dry weight percentage

Table 2. Chemical composition of commercial white flour and sugar beet powder

\begin{tabular}{lll}
\hline \hline Characteristics & $\begin{array}{l}\text { Commercial } \\
\text { white flour }\end{array}$ & $\begin{array}{l}\text { Sugar beet } \\
\text { powder }\end{array}$ \\
\hline Moisture (\%) & $11.0 \pm 0.1$ & $5.10 \pm 0.1$ \\
Crude protein (\%) & $10.0 \pm 0.2$ & $6.10 \pm 0.4$ \\
Ash (\%) & $1.40 \pm 0.1$ & $5.00 \pm 0.6$ \\
Crude fibre (\%) & $0.50 \pm 0.1$ & $9.00 \pm 0.1$ \\
Crude fat (\%) & $2.50 \pm 0.2$ & $0.80 \pm 0.1$ \\
NFE (\%) & $73.2 \pm 0.3$ & $74.0 \pm 0.6$ \\
TPC (mgGAE/g) & - & $1.18 \pm 0.8$ \\
DPPH (\%) & - & $79.1 \pm 0.2$ \\
TDF (\%) & - & $31.0 \pm 0.1$ \\
SDF (\%) & - & $10.0 \pm 0.6$ \\
IDF (\%) & - & $21.0 \pm 0.6$ \\
\hline \hline
\end{tabular}

$\mathrm{NFE}=$ nitrogen free extract; $\mathrm{TPC}=$ total phenolic content; $\mathrm{TDF}=$ total dietary fibre; SDF = soluble dietary fibre; IDF $=$ insoluble dietary fibre. 
of sugar beet powder from which the extract was obtained and was found to be $79.1 \%$. The values of DPPH in this study are in accordance with the previous studies by Sakac et al. (2004). These are presented in Table 3 and Fig. 1.

Dietary fibre content in wheat-sugar beet powder cookies. Total, soluble and insoluble dietary fibre content is presented in Table 4 and graphically expressed in Fig. 2. The values for total dietary fibre content of the cookies prepared from wheat-sugar beet powder composite flour (4-20\%) were ranged from 0.33-6.27\%. Insoluble and soluble dietary fibre content were ranged from $0.20-4.07$ and $0.13-2.20 \%$, respectively. The highest values were shown by $\mathrm{T}_{5}$ at $20 \%$ level and lowest by $\mathrm{T}_{1}$ at $4 \%$ level. The values for total, soluble and insoluble dietary fibre content in different types of wheat-sugar beet powder cookies were close to the findings of Rodriguez et al. (2006).

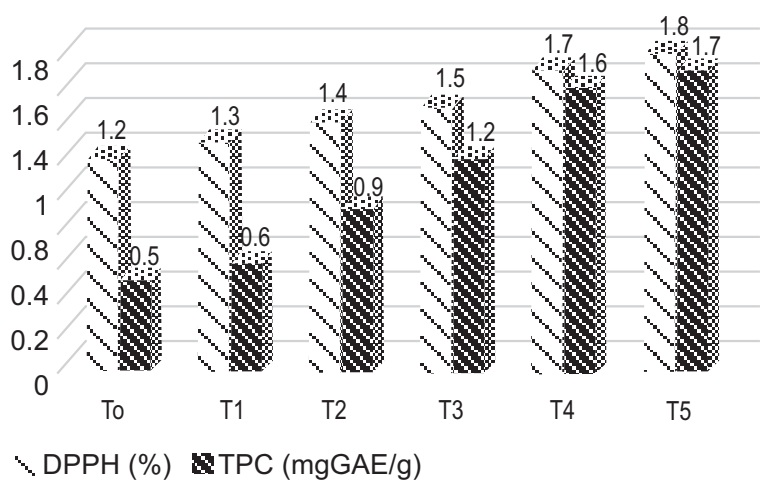

Fig. 1. Antioxidant profiling of sugar beet supplemented cookies.

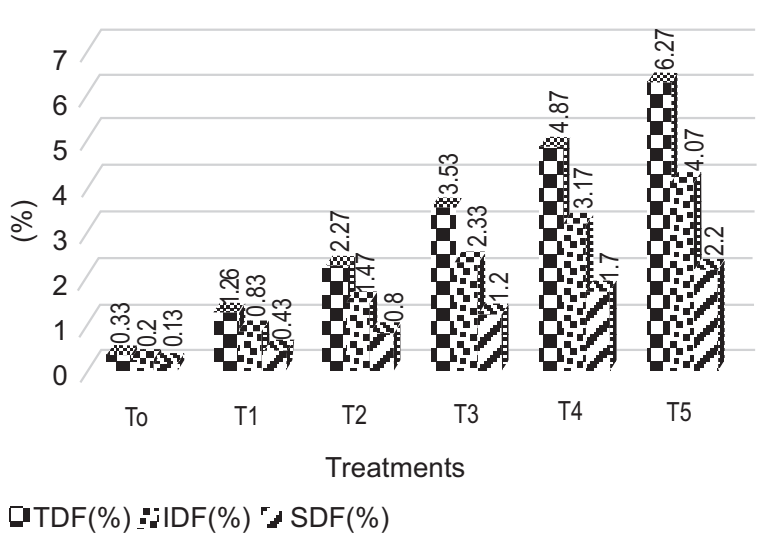

Fig. 2. Dietary fibre analysis of sugar beet supplemented cookies.
Total phenolic content and DPPH in wheat-sugar beet powder cookies. Total phenolic content and DPPH radical scavenging effect of sugar beet powder is shown in Table 3.

The values for TPC (mg GAE/g) and DPPH (\%) of the cookies prepared from wheat-sugar beet powder composite flour (4-20\%) were ranged from 0.6-2 mg GAE/g and 1.3-1.7\%, respectively. The highest value of TPC and DPPH was shown by $\mathrm{T}_{5}$ with a mean of $2 \mathrm{mg} \mathrm{GAE} / \mathrm{g}$ and $1.7 \%$ at $20 \%$ level and lowest by $\mathrm{T}_{1}$ with a mean of $0.6 \mathrm{mg} \mathrm{GAE} / \mathrm{g}$ and $1.3 \%$ at $4 \%$ level, respectively. The values for TPC (mg GAE/g) and $\mathrm{DPPH}(\%)$ in different types of wheat-sugar beet powder cookies are in accordance with previous study (Sakac et al., 2004).

Sensory evaluation of cookies. Sensory evaluation of cookies was conducted for different sensory attributes like colour, crispiness, flavour, taste, texture and overall acceptability. The sensory scores for all the above mentioned sensory attributes are shown in Table 5 and graphically expressed in Fig. 3. The scores were decreased highly significantly with increased substitution level of sugar beet powder in wheat-sugar beet powder composite flour cookies. The values of each parameter for sensorial characteristics were highest for $\mathrm{T}_{3}(12 \%)$ treatment and

Table 3. Antioxidant profiling of sugar beet supplemented cookies

\begin{tabular}{lll}
\hline \hline Treatments & DPPH (\%) & TPC (mgGAE/g) \\
\hline $\mathrm{T}_{0}$ & $1.2^{\mathrm{f}} \pm 0.01$ & $0.5^{\mathrm{f}} \pm 0.1$ \\
$\mathrm{~T}_{1}$ & $1.3^{\mathrm{e}} \pm 0.01$ & $0.6^{\mathrm{e}} \pm 0.1$ \\
$\mathrm{~T}_{2}$ & $1.4^{\mathrm{d}} \pm 0.01$ & $0.9^{\mathrm{d}} \pm 0.1$ \\
$\mathrm{~T}_{3}$ & $1.5^{\mathrm{c}} \pm 0.01$ & $1.2^{\mathrm{c}} \pm 0.1$ \\
$\mathrm{~T}_{4}$ & $1.6^{\mathrm{b}} \pm 0.01$ & $1.6^{\mathrm{b}} \pm 0.1$ \\
$\mathrm{~T}_{5}$ & $1.7^{\mathrm{a}} \pm 0.01$ & $2.0^{\mathrm{a}} \pm 0.1$ \\
\hline \hline
\end{tabular}

Table 4. Dietary fibre analysis of sugar beet supplemented cookies

\begin{tabular}{llll}
\hline \hline \multirow{2}{*}{ Treatments } & TDF & IDF & SDF \\
\cline { 2 - 4 } & \multicolumn{3}{c}{$(\%)$} \\
\hline $\mathrm{T}_{0}$ & $0.33^{\mathrm{f}} \pm 0.2$ & $0.20^{\mathrm{f}} \pm 0.1$ & $0.13^{\mathrm{f}} \pm 0.1$ \\
$\mathrm{~T}_{1}$ & $1.26^{\mathrm{e}} \pm 0.1$ & $0.83^{\mathrm{e}} \pm 0.1$ & $0.43^{\mathrm{e}} \pm 0.1$ \\
$\mathrm{~T}_{2}$ & $2.27^{\mathrm{d}} \pm 0.1$ & $1.47^{\mathrm{d}} \pm 0.1$ & $0.80^{\mathrm{d}} \pm 0.1$ \\
$\mathrm{~T}_{3}$ & $3.53^{\mathrm{c}} \pm 0.1$ & $2.33^{\mathrm{c}} \pm 0.1$ & $1.20^{\mathrm{c}} \pm 0.1$ \\
$\mathrm{~T}_{4}$ & $4.87^{\mathrm{b}} \pm 0.1$ & $3.17^{\mathrm{b}} \pm 0.1$ & $1.70^{\mathrm{b}} \pm 0.1$ \\
$\mathrm{~T}_{5}$ & $6.27^{\mathrm{a}} \pm 0.1$ & $4.07^{\mathrm{a}} \pm 0.1$ & $2.20^{\mathrm{a}} \pm 0.1$ \\
\hline \hline
\end{tabular}


lowest for $\mathrm{T}_{1}(4 \%)$ treatment as compared to control. Therefore, on sensory evaluation basis it was suggested that replacement of wheat flour with less than or equal to $12 \%$ sugar beet powder for cookies preparation gave the best overall acceptability of cookies and results were according to the findings of McWatters et al. (2003). Similarly, regarding particle size, colourless and odourless properties of these fibres have revealed better sensory characteristics of cookies (Sakac et al., 2010).

Table 5. Sensory evaluation of sugar beet supplemented cookies

\begin{tabular}{lllllll}
\hline \hline $\begin{array}{l}\text { Treat- } \\
\text { ments }\end{array}$ & Colour & $\begin{array}{l}\text { Cris- } \\
\text { piness }\end{array}$ & Flavour & Taste & Texture & $\begin{array}{l}\text { Overall } \\
\text { accept- } \\
\text { ability }\end{array}$ \\
\hline $\mathrm{T}_{0}$ & $7.2^{\mathrm{ab}}$ & $8.0^{\mathrm{a}}$ & $8.0^{\mathrm{a}}$ & $7.0^{\mathrm{ab}}$ & $8.0^{\mathrm{a}}$ & $7.2^{\mathrm{b}}$ \\
$\mathrm{T}_{1}$ & $7.2^{\mathrm{ab}}$ & $7.0^{\mathrm{ab}}$ & $7.0^{\mathrm{ab}}$ & $7.2^{\mathrm{a}}$ & $6.2^{\mathrm{bc}}$ & $7.2^{\mathrm{b}}$ \\
$\mathrm{T}_{2}$ & $6.5^{\mathrm{bc}}$ & $6.2^{\mathrm{bc}}$ & $6.2^{\mathrm{bc}}$ & $6.2^{\mathrm{b}}$ & $6.0^{\mathrm{bcd}}$ & $6.5^{\mathrm{b}}$ \\
$\mathrm{T}_{3}$ & $8.0^{\mathrm{a}}$ & $7.2^{\mathrm{ab}}$ & $7.8^{\mathrm{ab}}$ & $7.8^{\mathrm{a}}$ & $7.0^{\mathrm{ab}}$ & $8.2^{\mathrm{a}}$ \\
$\mathrm{T}_{4}$ & $5.5^{\mathrm{cd}}$ & $5.2^{\mathrm{cd}}$ & $5.2^{\mathrm{cd}}$ & $5.2^{\mathrm{c}}$ & $5.2^{\mathrm{cd}}$ & $5.0^{\mathrm{c}}$ \\
$\mathrm{T}_{5}$ & $4.5^{\mathrm{d}}$ & $4.5^{\mathrm{d}}$ & $4.2^{\mathrm{d}}$ & $4.2^{\mathrm{d}}$ & $4.5^{\mathrm{d}}$ & $4.0^{\mathrm{d}}$ \\
\hline \hline
\end{tabular}

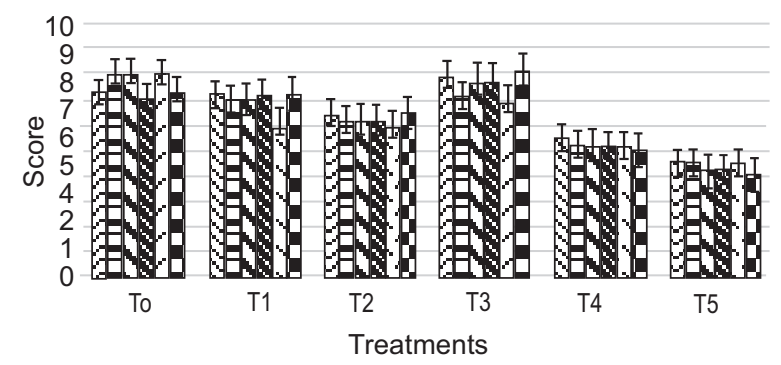

$\mathbf{8}$ Colour $\boxminus$ Crispiness $\$$ Flavour $\mathbf{\$}$ Taste $\square$ Texture $\boldsymbol{\nabla}$ Overall acceptability

Fig. 3. Sensory evaluation of sugar beet supplemented cookies.

\section{Conclusion}

In a nutshell, sugar beet a vital source of dietary fibre provides many potent benefits. Current research has revealed that sugar beet in cookies behaves as a remarkable source of dietary fibre. The chemical composition, dietary fibre estimation both individually as well as in composite form have shown significant results and can be a good source in bakery products as cookies. Exhibits a good in vitro antioxidant potential including total phenolic content and DPPH by its addition in cookies. It can be recommended to be used in our routine diet in order to improve fibre intake.

\section{References}

AACC, 2000. Approved methods of the American Association of Cereal Chemists. Methods, 54: 21 pp.

Ahmad, A., Anjum, F.M., Zahoor, T., Nawaz, H., Din, A. 2009. Physicochemical and functional properties of barley $\beta$-glucan as affected by different extraction procedures. International Journal of Food Science \& Technology, 44: 181-187.

Ahmad, S., Zubair, M., Iqbal, N., Cheema, N.M., Mahmood, K. 2012. Evaluation of sugar beet hybrid varieties under Thal-Kumbi soil series of Pakistan. International Journal of Agriculture and Biology, 14: 605-608.

Ainsworth, E.A., Gillespie, K.M. 2007. Estimation of total phenolic content and other oxidation substrates in plant tissues using Folin-Ciocalteu reagent. Nature Protocols, 2: 875-877.

Belal, I.E. 2007. Incorporating fodder beet Beta vulgaris cv. Majoral in Nile Tilapia (Oreochromis niloticus L.) diet. Emirates Journal of Food and Agriculture, 19: 22-30.

Brand-Williams, W., Cuvelier, M., Berset, C. 1995. Use of a free radical method to evaluate antioxidant activity. LWT-Food Science and Technology, 28: 25-30.

Filipovic, N., Djuric, M., Gyura, J. 2007. The effect of the type and quantity of sugar-beet fibers on bread characteristics. Journal of Food Engineering, 78: 1047-1053.

Galisteo, M., Duarte, J., Zarzuelo, A. 2008. Effects of dietary fibers on disturbances clustered in the metabolic syndrome. The Journal of Nutritional Biochemistry, 19: 71-84.

Kendler, B.S. 2006. Supplemental conditionally essential nutrients in cardiovascular disease therapy. Journal of Cardiovascular Nursing, 21: 9-16.

Lawless, H.T., Heymann, H. 2010. Sensory Evaluation of Food: Principles and Practices, 596 pp., Food Science Text Series, Springer-Verlag, New York, USA.

Lu, G., Edwards, C.G., Fellman, J.K., Mattinson, D.S., Navazio, J. 2003. Biosynthetic origin of geosmin in red beets (Beta vulgaris L.). Journal of Agricultural and Food Chemistry, 51: 1026-1029.

McWatters, K.H., Ouedraogo, J.B., Resurreccion, A.V., Hung, Y.C., Phillips, R.D. 2003. Physical and sensory characteristics of sugar cookies containing mixtures of wheat, fonio (Digitaria exilis) and cowpea (Vigna unguiculata) flours. International Journal of Food 
Science \& Technology, 38: 403-410.

Mohdaly, A.A., Sarhan, M.A., Smetanska, I., Mahmoud, A. 2010. Antioxidant properties of various solvent extracts of potato peel, sugar beet pulp and sesame cake. Journal of the Science of Food and Agriculture, 90: 218-226.

Montgomery, D.C. 2008. Design and Analysis of Experiments. John Wiley \& Sons, Inc., New York, USA.

Okpala, L.C., Chinyelu, V.A. 2011. Physicochemical, nutritional and organoleptic evaluation of cookies from pigeon pea (Cajanus cajan) and cocoyam (Xanthosoma sp.) flour blends. African Journal of Food, Agriculture, Nutrition and Development, 11: 5431-5443.

Piga, A., Catzeddu, P., Farris, S., Roggio, T., Sanguinetti, A., Scano, E. 2005. Texture evolution of "Amaretti" cookies during storage. European Food Research and Technology, 221: 387-391.

Ralet, M.C., Guillon, F., Renard, C., Thibault, J.-F. 2009. Sugar Beet Fiber: Production, Characteristics, Food Applications, and physiological benefits, Fiber Ingredients: Food Applications and Health Benefits, pp. 359-392, CRC Press, Boca Raton, FL, USA.

Rodríguez, R., Jimenez, A., Fernández-Bolaños, J., Guillén, R., Heredia, A. 2006. Dietary fibre from vegetable products as source of functional ingredients. Trends in Food Science \& Technology, 17: 3-15.

Sakac, M.C., Gyura, J.F., Mišan, A.C., Šereš, Z.I., Pajin, B.S., Soronja-Simovic, D.M. 2010. Antioxidant activity of cookies supplemented with sugarbeet dietary fibre. In: Proceedings of the $5^{\text {th }}$ International Congress Flour-Bread' 09. $7^{\text {th }}$ Croatian Congress of Cereal Technologists, Opatija, Croatia, 21-23 October, 2009, pp. 76-83.

Sakac, M.B., Pericin, D.M., Mandic, A.I., Kormanjos, Š.M. 2004. Antioxidant properties of ethanolic extract of sugar beet pulp. Acta Periodica Technologica, 35: 255-264.

Schnyder, G., Roffi, M., Flammer, Y., Pin, R., Hess, O.M. 2002. Effect of homocysteine-lowering therapy with folic acid, vitamin B12 and vitamin B6 on clinical outcome after percutaneous coronary intervention: the Swiss Heart study: a randomized controlled trial. Jama, 288: 973-979.

Škrbic, B., Duriic-Mladenovic, N., Macvanin, N. 2010. Determination of metal contents in sugar beet (Beta vulgaris) and its products: empirical and chemometrical approach. Food Science and Technology Research, 16: 123-134.

Thibault, J., Renard, C., Guillon, F., Cho, S., Dreher, M. 2001. Sugar beet fiber: production, composition, physicochemical properties, physiological effects, safety, and food applications. Handbook of Dietary Fiber, pp. 553-582.

Vulic, J., Canadanovic-Brunet, J., Cetkovic, G., Tumbas, V., Djilas, S., Cetojevic-Simin, D., Canadanovic, V. 2012. Antioxidant and cell growth activities of beet root pomace extracts. Journal of Functional Foods, 4: 670-678.

Westenhoefer, J. 2001. Establishing good dietary habitscapturing the minds of children. Public Health Nutrition, 4: 125-129. 